\title{
URBAN STRATEGIES AND COLLECTIVE MEMORY. AN UPPER-MIDDLE CLASS MUNICIPALITY IN THE GRAND PARIS PROJECT
}

\author{
Yankel FIJALKOW \\ UMR LAVUE CNRS 7218, Paris, France
}

\begin{abstract}
This article proposes a theoretical point of view in order to show the importance of the collective memory and the urban narrative in the strategic approach of the urban project. The capacity of a municipality to build a local narrative joining the past, the memory and the project, is examined in the second part of the article, in a case study of a collectivity confronted with the project of the Grand Paris and strong socio-spatial transformation since 1950. The conclusions of thirty deep interviews, conducted on the people involved in the city organization allow to differentiate legitimated and rejected places in the spaces of remembering, and the difficulties of this kind of municipalities to be pro active in the Grand Paris project.
\end{abstract}

Key Words: collective memory, urban planning, local narrative, social urban geography, cognitive geography.

As the growing publications on Memory Studies mobilize a variety of disciplines (Erll, 2008) it interests as much geographers of culture as those who study town planning and territorial development. Indeed, as collective memory steads in "commemorative sites" (Nora, 1974), it is also present in the decision of planners.

How this dimension can be harmonized with strategic analysis, which is a foundation of urban studies? This article proposes a theoretical point of view and shows the importance of the urban narrative. The capacity of communities to build a local narrative joining the past, the memory and the project, as it will be shown in the second part of the article, is examined in a study of a municipality confronted with the project of the Grand Paris.

\section{A cognitive and a strategic hypothesis about city planning policy}

Territory's organization, location of amenities, construction and allocation of housing, transportation, treatment of neighborhoods and protecting the environment are classic subjects in a city planning policy. Although strongly supported by legal instruments, city planning policy is also seems to be based on implicit rules about the collective modus operandi and agreements between elected officials, technicians and users that allow for a analysis of "government of the city" (Gaudin, 1999). Theories have been developed to describe these different processes in the wake of Max Weber's groundbreaking research. In 1922, Weber described "conflicts of legitimacy" between social groups and professionals who wanted to gain total control over what he called the "urban political economy". By showing that a political logic existed in cities, Max Weber largely contributed to the debates of his time about the administrative and political autonomy of cities within the framework of the German state.

On another scale, we know, since Jones (1970), that public decision-making articulates the fit between the formulation and legitimization of solutions in a complex manner. As such, the first 
sequence, which involves putting an issue on the "agenda" (which can be done by institutional agents, experts or non-profit groups), influences the second sequence, which is based on the actual solution. A decision is thus a collective process in which each actor has limited vision and thus partial rationality. This principle underpins the study of systems of action that depends on a plethora of interacting public and private actors; it justifies research into public action networks (that is, private/public, non-hierarchical coordination between organizations that are familiar with each other)which can constitute growth coalitions in cities that mobilize local political and economic elites (Logan and Molotch, 1997). Such multi-level public action configurations have flourished in the current context of the decline of the Welfare State; this has most affected local municipalities and NGOs (Atkinson and Coleman, 1989). But public actor networks which inevitably require regulation are also dependent on the use of legal and material resources, knowledge and representations of their territories. The notion of a "public policy referential" is meant to bring together values, representations, arguments and public policy projects (Muller, 1990). To better understand them, we need to combine a cognitive approach and a strategic approach.

The cognitive approach, which consists in inventorying the "stock of knowledge" of the actors, is connected to the collective memory (Berger and Luckman, 1966) : what the actors know, what they remember. It defines itself in opposition with the history as a social wave, which realizes the memories of the group. It gives it cohesion and identity (Halbwachs, 1925). In the city, the collective memory reflects the recognition of the social groups and their capacity to appropriate their territory. It constitutes an important stake, in particular in the context of the post fordist city and globalization, strengthening the economy of leisure, exchanges and migrations, identical mechanisms and attractiveness of cities (Florida, 2003).

The strategic approach, inspired by the sociology and geography of organizations, is based on the principle that "actors" get autonomy of decision inside their "margin of action". This theory, which emphasizes the "zone of uncertainty" of each, includes strategies of individuals and local groups (Hassard, 1995).

\section{Urban narratives}

What is the role of narrative, and more specifically of a narrative based on collective memory, in the creation of a system of action? Is the memory of cities a resource for collective action? Decisions to erase builts - by voluntarily burying or demolishing them - and moves to rehabilitate or renovate them are the result of the shared desire of local groups. The memory of cities exists through the marks and the traces of local actors; these cannot be physically erased since they are no longer labile. They are expressed through narratives, slogans, photographs, film sequences and buildings. We can identify cities that are "full of traces and marks", that have been molded by social and spatial changes and are accustomed to the perpetual transformation of their destiny: they are composed of a diverse array of buildings and social groups which reactivate the memory of places. At the opposite end of the spectrum are cities without memory, which, like new towns or planned cities, have trouble, finding their place in the present and the future.

Indeed, given that politics mobilizes the past and uses it for its own ends, the policy of memory is an urban policy for the present. And yet, while the traditional functions of the city (safety, supply, solidarity) are exercised by certain categories of legitimate citizens, who among them has sufficient legitimacy to impose a narrative that embodies collective memory and a project? It is common to see numerous groups come together to lay down marks in the city at the site of labile traces that are threatened with being forgotten or by the existence of adverse groups. 
Yet, those traces, which become marks, are those which have meaning for the collective memory of contemporary actors. As such, the contemporary territory of a neighborhood or a city can appear in the form of spaces of prime importance, spaces of attachment, spaces of detachment or rejected spaces which connect the past to the present, strategies and representations.

Over the past few years, city planners have begun to show an interest in urban narratives. Walter Benjamin's The passageways of Paris (1939) are of interest to them since they illustrate how cities were competiting over their image even in the first half of the $20^{\text {th }}$ century (Keith, 2008). For example, the Great Exhibition of 1851 presented London as a city of power, tolerance and consumption. This narrative established a symbolic order which expressed itself through cards, texts and artistic creation. Such narratives have the power to define what exists and what does not. Some North American authors have drawn parallels between the importance of urban narratives and that of the memory of ethnic minorities (Hayden, 1995).

As such, the types of artistic expression that tell the story of a city are particularly strategic. Vanolo (2007) has underscored their importance in the context of the Post-Fordist city, connected to the emergence of a creative social class. The latter is less connected to institutional and industrial economic structures than to the development of values presented as positive by a dominant culture: multiculturalism, tolerance, respect for nature. The narrative of these global cities involves promoting the work of famous architects and of creating buzz about the city based on events, and notably through circulating images of public space that show groups that illustrate open-mindedness and tolerance. As such, the old French industrial city of Saint-Etienne, which is currently mired in economic crisis and torn between "productivists" and "creatives", has found a way to unite different social groups through the promotion of an industrial design (Dormois, 2007). And so we may consider that urban narratives can express a city's spatial frame of reference, meaning contemporary ways of thinking that are inherited from the past, and ways of thinking about the future according to values and norms shared by social groups.

\section{A high middle class municipality in the Grand Paris project}

We will test the notion of urban narrative on a large city in the Greater Paris lle-de-France region $\left(85,000\right.$ inhabitants, the $51^{\text {st }}$ largest city in France) by showing how its collective memory, which is connected to its social composition, structures its relationship with the Grand Paris urban renewal project. Our research is based on thirty in-depth interviews conducted with the local elites (elected officials, public service directors, people in charge of non-profit groups) tasked with plotting the City's future direction. In order to help construct a local project within the context of the Grand Paris project, we asked departmental heads, elected officials, people in charge of non-profit groups and local historians to describe and tell us the relevant memory of the city and its places. Besides these interviewes treated qualitatively, we conducted with half of them "commented itineraries" consisting in visiting and recording their words on the portions of the city and the memories sites who appear significant. In this article we present a synthesis of the most wide spread quotations which reflect the social environment of the active persons in the city ${ }^{1)}$. How can the municipality of Courbevoie positions itself in terms of its unity, centrality and future? What can collective memory contribute to a project that integrates all of these aspects? These questions concern closely this municipality inserted into specific spatial constraints, inherited from its history. First, this city is located in the extension of the

1) The quoted places reflect at least two thirds of the interviews. We reported in this text the most illustrative extracts of interviews in a quantitative and a qualitative point of view. 
large thoroughfare which runs from the Louvre to La Défense and along another Royal Road (less well-known as it cuts through poor areas) which runs from Saint-Denis (the Tombeaux des rois de France - royal tombs) to Versailles. In the latter direction, Courbevoie belongs to the working class municipalities along the river which were industrialized in the early $20^{\text {th }}$ century (Saint-Denis, Villeneuve, Asnières, Puteaux). In the other direction lie the affluent municipalities of Western Paris such as Neuilly for example. As we see in the map 1. below, the city of Courbevoie is thus transected by external traffic flows which sub-divides it into heterogeneous neighborhoods: the neighborood of "Becon" is cut off by the Boulevard de Verdun and La Défense is delimited by the belt highway (boulevard circulaire) to give only the two most striking examples.

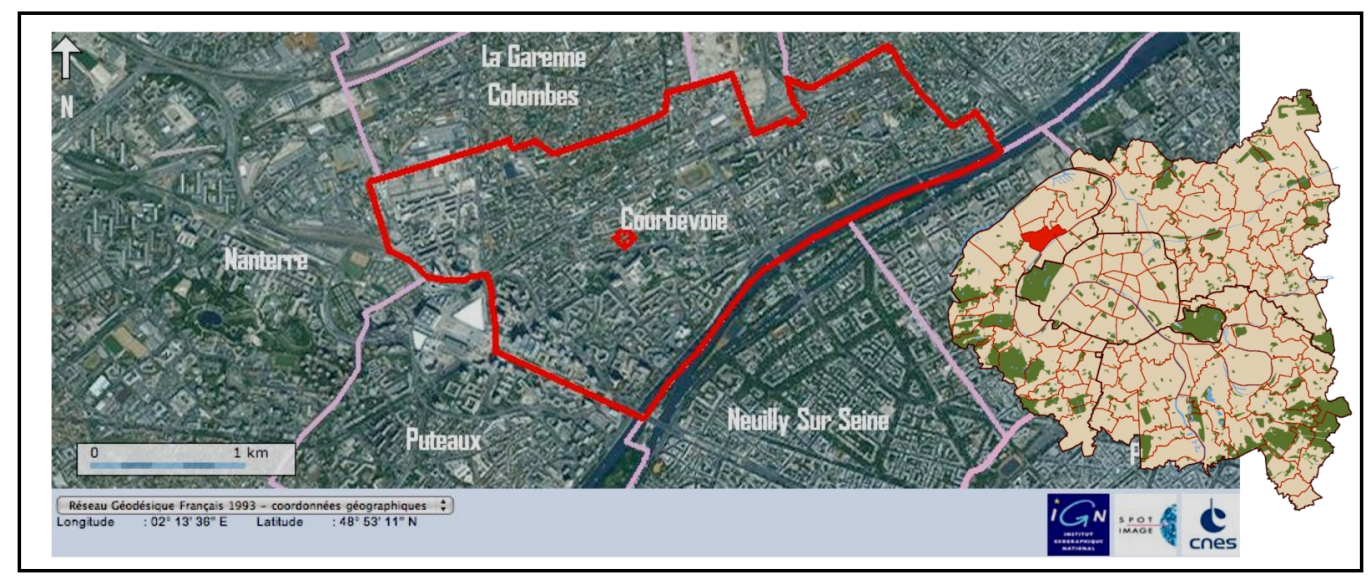

Fig. 1- Localization of Courbevoie in the lle de France Region Source : Aerial view (CNES), lle de France Region (IGN) ${ }^{2)}$

Second, this municipality is identified with the business district La Défense, both an incursion on the landscape and a source of revenue. Courbevoie's centrality was modified at the start of the 1960s when the La Défense was created. The French government initiated the operation in an attempt to palliate the lack of office space in Paris and make the French capital a "truly global city". In September 1958, the government created the Development Authorities of La Défense $(E P A D)$ to build, to manage, and to rejuvenate the sector; the project was imposed on local municipalities through an aggressive strategy. As such, EPAD's partners were the French government and the municipalities of Puteaux and Courbevoie, which had right-leaning local governments. The first buildings, including the Esso tower and the Nobel tower, were built in the following years and slowly replaced the engineering and automobile factories, the neighboring shantytowns and a few farms. The French President inaugurated the Center of New Industries and Technologies (CNIT) in 1958. The French government in 1964 approved an initial development plan. It was modified at the start of the 1970s to increase the scope of built surface space. The "La Défense district" extends over a large pedestrian mall of 31 hectares that is raised above natural ground level. It is shared by the municipalities of Puteaux and Courbevoie and is surrounded by a long, one-way belt highway.

This large office park includes 3 million square meters of office space, $600000 \mathrm{~m}^{2}$ of housing, a shopping center, 180000 employees (of which 80000 work in Courbevoie) and 20000

2) CNES: Centre Nationale d'Etudes Spatiales. IGN: Institut Géographique National 
inhabitants (of which 10000 live in Courbevoie). In 2010, EPAD was merged with the development authority for Seine-Arche (EPASA), which was formed by the communist municipality of Nanterre in order to conduct a global project on one of the major territories of the Grand Paris project. As such, starting in the 1960s, the French government imposed a new structure and created a complex relationship between three municipalities whose goals differed. For Courbevoie, La Défense has meant a rupture in the territory, but also a source of tax revenue from the business taxes paid by companies based on their turnover. Indeed, such taxes represent more than half of local tax revenue but this has not prevented Courbevoie from setting taxation at rates two times below the national average.

Third, the former working class municipality has fastly become a high middle class locality, what differentiates it to the close municipalities remained popular as Nanterre.

In Courbevoie in the 1960s, industrial activity was shared between precision engineering (automobile, aviation) and large perfume laboratories. These activities gradually disappeared in the thirty years after World War two and were replaced by service industries. Following the La Défense operation, housing prices soared alongside office real estate prices. A strong demographic shift occurred putting the working class population in the minority within a few decades (less than 10\% in 2000 compared to $48 \%$ in 1954) while well-off professionals and socio-professional categories increased significantly $(39 \%$ in 2000 , compared to less than $8 \%$ in 1954). Although the presence of a middle class has limited the risk of social polarization (Préteceille, 2005), such rapid transformation has nonetheless represented a veritable gentrification, meaning the replacement of less well-off social categories by wealthier ones, a shift in the working population from the primary sector to the tertiary sector, an increase in the percentage of home owners (22\% in 1962, 29\% in 1982 and $42 \%$ in 2000), and a certain degree of social mix judging from the distribution of professional categories in different subneighborhoods (see the diagram).

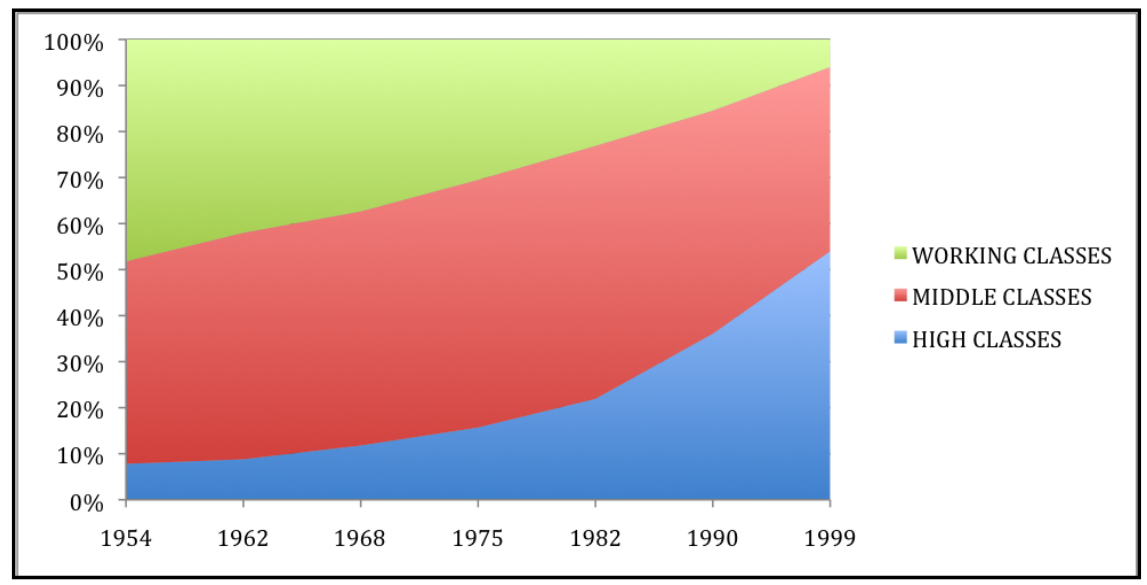

Fig. 2 - Social status of population in activity (1954-2000) $)^{3)}$

(Sources: census of population, retrospective datas)

3) High classes: liberal professions, senior executives, business managers. Middle classes: employed, middle managers, storekeepers, intermediate occupations. Working class: workers, staffs of services 
We should add, however, that even if Courbevoie include nearly $20 \%$ social housing (a requirement in France since $2000^{4)}$ ) and $42 \%$ of privately-owned homes, mixed sectors with both social housing and owned (or mortgaged) homes are rare.

Fourth, Courbevoie became the 5th densest city in France; this is visible from the height of its high-rise apartment buildings. Between 1954 and 2000, there was a vigorous renewal of built infrastructure. Only a small percentage of houses built before 1871 remains; those built after 1949 now represent about three quarters of housing. The uncomfortable dwellings without indoor plumbing that counted over $40 \%$ of dwellings in 1954 are now only about $3 \%$. Furnished rooms, which were facets of working class housing, especially for single immigrant workers, dropped from nearly $6 \%$ of dwellings in 1962 to an insignificant number in 2000. Due to its proximity to La Défense, Courbevoie was extremely sought after by private developers in the 1960s, who often took a tabula rasa approach and advocated planning based on slabs and towers. The municipality sets up financial partnerships with developers within the scope of local government planning projects. This trend has made the few remaining pre-war buildings, especially the detached houses - which make up about $3.7 \%$ of main residences according to the census - really stand out. But, as we shall see, these buildings have now become highly prized by the city's elites.

All theses factors product a strong spatial division into very individualized neighborhoods. In Courbevoie, according inhabitants, the roads that dissect the territory delimit the neighborhoods. They are also identified according to the city's points of entry.

- $\quad$ The La Défense residential neighborhood is cut off by the raised pedestrian area and the belt highway. It is accessible via the Paris subway and RER commuter train.

- A new neighborhood called the Faubourg de l'Arche was built on industrial land for wealthier social categories working in La Défense. It is clearly delimited by a boulevard undergoing renovation and a tramway line under construction.

- $\quad$ One of the oldest neighborhoods is Becon, accessible by a train station that is five minutes from Paris. This neighborhood is old, traditional middle class and is delimited by a true clearing in the city.

- Morever there is lower Courbevoie which also has a train station. It is a former working class district that has been completely transformed by high-rise buildings, municipal offices and a shopping center built in the 1960s with already obsolete slab architecture. This district is a neighborhood by default since there is no actual center.

In this context, what are the influential local groups on the urban policy? In fact, the distribution of influential local groups is a reflection of the city's landscape: the new economic base of the municipality includes people who work in the financial sector at La Défense. These groups embody values such as efficiency and profitability. They are part of a globalized social class that, when interested, use public services as customers. The way they use the city pays little attention to its memory. At the opposite, the traditional base, connected to the municipal government, reflects the established traditional high middle class (advocates, doctors, business managers, trading bourgeoisie) and is well represented in the Becon neighborhood ${ }^{5}$. It favors a paternalistic approach to managing the city. The public housing office and leisure and social

4) According to the article 55 of the law Solidarity and Renewal Urbain (2000), municipalities of more than 3500 inhabitants have to contain at least $20 \%$ of social housing on their territories.

5) Since 1945 , the municipal majority is situated to the right of the political scene. In the last municipal elections the party Union for the Presidential Majority win $58,7 \%$ of the votes. 
services offer personalized service to residents based on a relationship of proximity that is surprising for a city with 85000 inhabitants. The La Défense operation was imposed on this group and it negotiated the various real estate operations that radically transformed the city.

\section{A strategic position in the Grand Paris project}

Since it is linked to La Défense, Courbevoie is also subject to the Grand Paris project that aims to transform the Paris urban agglomeration into a large global metropolis. The project was the focus of a highly mediatized international tender for architectural ideas. Concretely, it corresponds to the government's creation of a transportation network connecting the major economic poles around Paris (Fig.2 below). A company called the Société du Grand Paris was created to build a new automated subway in the Paris suburbs.

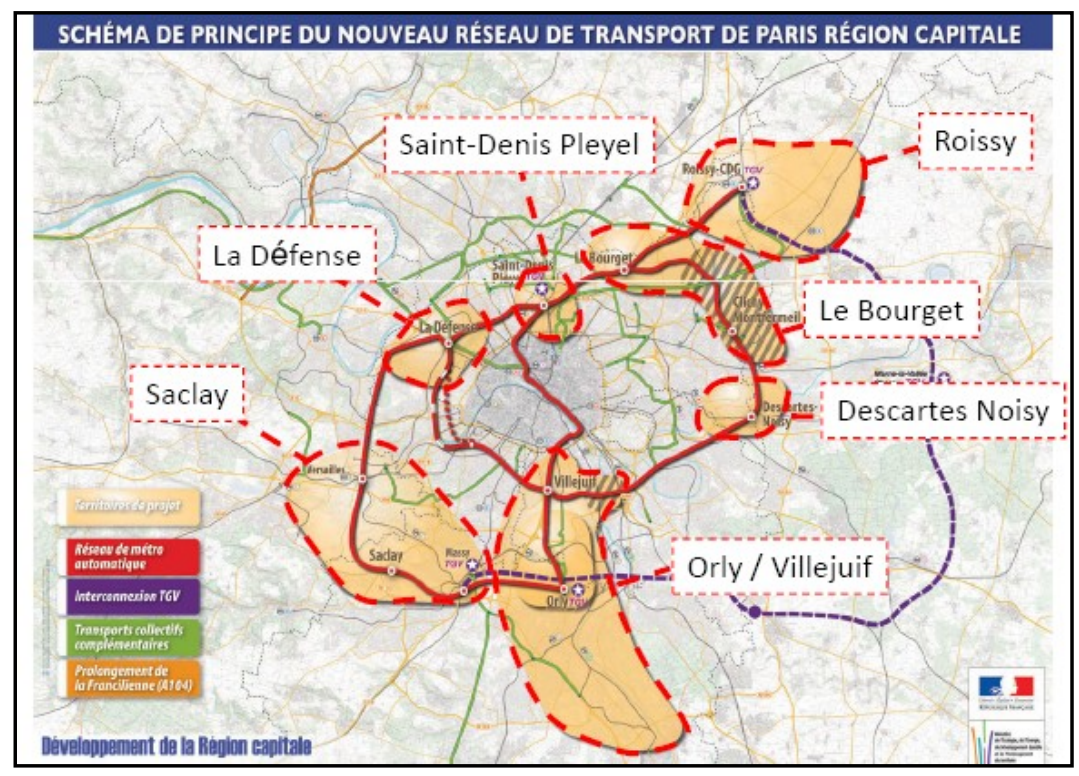

Fig. 2 - Grand Paris master Plan : Courbevoie is on the financial cluster for La Défense

(Source : Law report on the Grand Paris, may 2010)

http://www.le-buzz-immobilier.com/wp-content/uploads/2010/05/le-grand-paris-transports.jpg

At the institutional level, the government's Grand Paris project will merge Paris and the inner suburbs' administrative départements in line with the desire for legislative municipal reform. This scheme is in opposition to Paris Métropole, which is a joint association that includes the City of Paris, the lle-de-France region and several dozen local authorities in the agglomeration which tend to have left-leaning local governments. It also opposes the lle-de-France region's new outline development plan (SDRIF), also backed by the opposition. Financially speaking, the project could result in a better distribution of business taxes between municipalities; this is a problem for cities that have benefited from La Défense since its creation, including Courbevoie, which has many public services and low housing taxes. Talks about this are ongoing. Recently, the government-appointed Secretary of State in charge of development in the Greater Paris Area (meaning the person is a quasi-minister) suggested the creation of major economic poles 
around Paris, as well as the creation of a primary transportation network for Grand Paris that would connect the poles to the airports, high-speed train stations and downtown Paris. This Secretary of State has also called for the creation of a public authority in charge of development, city planning and the creation of competitive "clusters", e.g., a "scientific cluster" for the Saclay plateau" and a "financial cluster" for La Défense.

Overall, the municipality of Courbevoie supports the Grand Paris project that allows the La Défense operation to continue: "without economic growth, there is no distribution" said a municipal councilor from the majority who also admitted that "La Défense does not need to be more connected to its environment" and who advocated "local city planning". It appears that although the municipality wants to continue deriving benefit from La Défense, it no longer wants to be subjected to it as it was in the three decades following World War Two. It has been cautious about government policy which, since 2000 , has tended to reduce the number of local municipalities in France and promote municipal consolidation. Another municipal leader said, "Courbevoie has begun consolidation work with Puteaux and is involved in strategic thinking with five other municipalities in the département". The terms have been cautiously set out.

It express the behalf of the traditional local political group of Courbevoie, supporting the governmental project and by way the maintain of an economic position within the Parisian conglomération (La Defense's compagnies and the sharp rises of the real estate prices ${ }^{7)}$ ) leading to the replacement of the old owners by more fortunate, young households (Monteiro, 2010). But the risk of a "disappearance" within the Grand Paris project and the "explosion" of the city in several different entities worry the elected representatives. Courbevoie traditional population is worried about its "deterritorialization", meaning its ability to control dynamics across its territory. So, the actions of town planning consist so much in strengthening the dynamics registering Courbevoie in the Grand Paris where to rediscover a long time forgotten heritage. These two options reflect the memory of a compulsory town planning.

\section{A transected city, an inheritance of an imposed town planning}

Negative narrative illustrates a kind of fatalism about the city's bygone days. With regard to past urban renewal projects, we often heard that "Courbevoie was subjected to La Défense" and that the construction of public housing "was imposed by La Défense to re-house the population". Similarly, a person elected in the 1960s stated that, "We could not really tell what the blueprints and models were going to become", which highlights their fatalism as an elected official without any critical means of confronting the engineers. More recently, the city had to accept the closure of popular public services for financial reasons, such as medical clinics and the maternity ward which structured Courbevoie's territory. "People are no longer having babies in Courbevoie", declared the person in charge of social work who saw in this fact the city's inevitable demise. Such rhetoric also reflects a representation of the city as fractured and riven with outside elements such as the Faubourg de l'Arche neighborhood and public housing highrise apartment buildings. The residents of the former are of higher social status and are perceived as "demanding", "consumerist", "intrusive" and "participatory", "demanding efficient management methods from the private sector" and "able to vote with their feet" (and leave the city), which increases the pressure they can exert and the local government's efforts to try and keep them. Inhabitants of social housing are viewed with the traditional distrust shown for poor populations. People often forget that they have lived in Courbevoie for several generations and are sometimes those who were re-housed by the La Défense project. Thus, there is a

6) In the Paris's Region this place is occupied by a High scientific research park.

7) This study on real estate shows an evolution of the number of sales : $42 \%$ in five years. The average price was $2100 € / \mathrm{m}^{2}$ in 2000 , and doubled to reach $3900 € / \mathrm{m}^{2}$ in 2005 . 
supposedly "real Courbevoie" alongside these outside elements. It is in the context of representing this "real Courbevoie" that the municipal majority group has been considering implementing a local zoning plan intended to provide a real measure of control over the territory.

In the same way, many people stated that Courbevoie is particularly renowned for the high number of house moves which are proof of the population's trouble settling down. However, census data compared to the neighboring 92 département tend to put this information in perspective. It seems above all that the 1500 house moves per year based on moving authorizations requested from the city's technical services department reflect major moves by families, most often home owners, rather than young couples and students. And yet, even if the idea of mobile inhabitants needs to be qualified, it nonetheless influences development plans. Indeed, Courbevoie is often seen as a "transected city that lacks unity": transected by populations that do not settle down, and transected by automobile flows that also come from outside.

As the impression of a transected city, where household move a lot, the vision of a city divided by districts and by social housing block (in particular in the city center) participates in the feeling of a lack of identity. This perception often returns in the history of the city. But while it concerns in 1970s very precise social housing block, it corresponds in 2000 , to the sector of the Faubourg de l'Arche, recently built. As we have mentioned, many people are worried that the neighborhood is not part of the rest of the city and is totally identified with La Défense. We were told that, "many residents in this neighborhood do not realize that they live in Courbevoie". "They do not attend the meetings organized by the municipality." And, "the construction of a tramway line risks separating the neighborhood from the rest of the city..."

\section{Futuristic and passeist answers}

The answers to this imposed town planning consist at once in integrating the offices high rise towers of La Defense by getting closer to the futuristic model of Grand Paris and to refocus on the mythical inheritance of the former housing stock.

The first approach led to widespread establishment of new high rise towers along the belt highway, compelling large multinational firms to acquire an address and a public entrance on the street (a concept that had disappeared from modernist discourse). But it has also conversely resulted in the construction of two residential high-rise buildings for extremely highincome families near Neuilly bridge (the Hermitage towers, main contractor: Skenderov; architect: Foster); this has meant that poor families living in public housing have had to move out. This project is part of the government's "financial cluster" idea. There is a risk that the extremely high real estate prices associated with this operation will attract other very high income groups and that the project will have a knock-on effect on prices in the ordinary local market. Yet this detail seems to matter little compared to "the beauty" of the project which symbolically marks the entrance to Courbevoie. Similarly, the Phare tower project (architect: Tom Mayne) was announced in 2009 by the French President to inaugurate the renewal of La Défense. It is currently the subject of heated debate due its $350 \mathrm{~m}$ height and the environmental problems it will create. But it is located in the neighboring municipality of Puteaux, and opinions are divided in Courbevoie, including among the municipal majority group. The municipality has not overtly intervened with the neighboring mayor, but has discretely encouraged its inhabitants to express their opinion during the public enquiry preceding the granting of a building permit.

This strategic position has also resulted in the rediscovery of old buildings and almost 
accidentally of the green corridor. Oddly, while the city has been profoundly modernized and contains very few old buildings, local leaders have become very interested in the city's built heritage. Around 1980, a former elected municipal official active during the period of urban renovation published a postcard album about old Courbevoie. In 2000, the director of the Mayor's office published a book on the "Spirit of Courbevoie". Furthermore, the city has multiplied the number of guidebooks in which there is a catalogue of remaining old buildings. Guided tours are available. And yet at the planning level, the city has never taken any active measures to protect or save its heritage. It was not until a small group of residents (composed of architects, artists and intellectuals) from the small, privately-owned houses located extremely near La Défense legally attacked the zoning plan that the municipality agreed to protect their area. This compromise needs to be kept in perspective, but it nonetheless marked a change in attitude compared to the former municipality that would never have accepted a compromise that challenged the modernity of La Défense.

\section{A map of collective memory, legitimate or not}

The desire to more effectively control city planning has strengthened the city's awareness of its heritage. When we ask the local actors, six places (more often called places than spaces) are unanimously presented to be the legitimate memory of the city. Their common characteristics consist in their prestige because of their localization, and their link with the national and social history, often connected in Paris, as the capital city.

- The Becon garden is located in the city's old middle class district; it is where fragments of the city's memory remain (the pediment of the former fire station, pavilions from the Paris Universal Exposition);

- The Pont de l'Aigle bridge (commemorating the transfer of Napoleon's ashes);

- The library built by Garnier (architect of the Paris Opera house);

- The former town hall, with paintings representing the Seine and Neuilly, as seen from Courbevoie;

- The Saint-Pierre Saint-Paul church, the only church to have been built by the French Revolution;

- The sports stadium built in the 1920 s and recently classified as a Historical Monument by the French government. It is nonetheless disparaged for its "Stalinist architecture", probably because of the slightly left-leaning orientation of the mayor at the time.

The issue raised by the stadium is telling. Indeed, interest in the city's heritage is selective, notably regarding things that represent the municipality's working class past. Of course the elites (including an elected official who was a former boilermaker) remember the renovation and industrial zones and working class housing zones present at the start of the 1960s. They are even "nostalgic for the worker solidarity that reigned in Courbevoie", as one of them said. But this recollection has very little concrete basis today despite some elements still present in the landscape.

As such, during our interviews, the so-called Habitation Bon Marché ${ }^{8)}$ built in the 1920 s and $1930 \mathrm{~s}$ in rose-colored brick are not included in the heritage discourse due to the population that lives there, which is perceived as "foreign" to the municipality. And yet Courbevoie's official guidebooks promote this type of architecture so the notion of heritage that should unite all inhabitants actually does the opposite and divides them.

8) «Cheap housing»: former appelation of the social housing before 1950. 
In the same way, local leaders who want to give Courbevoie back a real downtown area (and not a simple modern market center we know today) do not make any connection between the loss of centrality and the transfer of the open-air market, which was the backbone of popular sociability.

As such, the collective memory of Courbevoie is composed of legitimate elements - marks which identify it among the well-off Western Paris municipalities, and of relatively discreet traces which are the basis of its continuity with neighboring more working class municipalities such as Nanterre and Puteaux.

\section{Conclusions}

Within the scope of a cognitive and strategic study of public policy, the case of Courbevoie seems to clearly reflect the weight of memory in establishing a city project. Indeed, although the city of Courbevoie that presented itself as the city of "perfumes and precision engineering", has disappeared, a municipality that ignores its collective memory and its continuity with the surrounding municipalities will be unable to develop a project that has the backing of its inhabitants. If the surrounding municipalities are not taken into account, the risk of deterritorialization, against which elected officials are reacting in attempting to develop a policy of negotiated control over city planning, may drift towards "museum-ification": i.e., strict regulation of the conditions under which the city and its heritage evolve.

On a theoretical level, it is obvious that even in the futuristic context of Grand Paris, urban narratives are kept up by local groups and continue to weigh heavily on the present. This confirms the relevance of crossing the cognitive approach (what the actors know, what they remember) and a strategic analysis, in particular the best-settled local group. For urban geographers it's important to notice that local identity turns out fragile when it leans on a space of legitimate memory arousing more divisions than cohesion. But in the context of competition between cities and big projects urban as that of the Big Paris, this dimension seems to be minor.

At least, it is a pity that collective memory was not incorporated into the broad consultation process on the future of Grand Paris. But we may understand why.

\section{References}

ATKINSON M., COLEMAN W. (1989), Strong states and weak states : sectoral policy network in advanced capitalist Economies, British Journal of Political Science, 19 (1), p. 46-67. BERGER P-L., LUCKMANN T. (1966), The Social Construction of Reality: A Treatise in the Sociology of Knowledge, Garden City, NY, Anchor Books.

DORMOIS R. (2007), Creativity in the Governance of The European Industrial Cities : Process, Outputs and Limits, Proceeding of the 11th of the International Society for the Study of European Ideas.

ERLL A. (dir) (2008) Cultural Memory Studies: An International and Interdisciplinary Handbook, London, Walter de Gruyter.

FLORIDA R. (2003), The Rise of the Creative Class: And How It's Transforming Work, Leisure, Community and Everyday Life, New York, Basic books.

GAUDIN J-P. (1999), Gouverner par contrat, l'action publique en question. Paris, Science Po.

HASSARD J. (1995) Sociology and Organization Theory: Positivism, Paradigms and

9) Postal stamp 
Postmodernity, Cambridge University Press.

HALBWACHS M. (1925), Les cadres sociaux de la mémoire, Paris, Albin Michel, 1994.

HAYDEN D. (1995), The Power of Place: Urban Landscapes as Public History,

Cambridge, MIT Press.

JONES C. (1970), An introduction to the Study of Public Policy, Belmont, Wadsworth. KEITH, M. (2008), Walter Benjamin, Urban Studies and the Narratives of City Life, in A Companion to the City ( $\mathrm{G}$. Bridge and S. Watson, eds), Blackwell.

LOGAN J-R., MOLOTCH (1997), Urban fortunes, the political economy of place. Berkeley: University of California Press.

MONTEIRO F. (2010) Les ventes immobilières à Courbevoie 2005-2008, Rapport de

stage, Université Paris 10 Nanterre (Y.Fijalkow, dir).

MULLER P. (2003), Les politiques publiques, Presses Universitaires de France, 1990. NORA S. (1974), Les lieux de mémoire, Paris, Fayard.

PRETECEILLE E. (2007), Is gentrification a useful paradigm to analyse social changes in the Paris metropolis?, Environment and Planning A.

VANOLO A. (2007), Urban images and the creative city, Proceeding of the 11th of the International Society for the Study of European Ideas. WEBER M. (1922) The city, Free Press, 1966.

Received at : 01.11.2010

Revised at: 03.12.2010

Accepted for publication at: 15.12.2010 